\title{
Priority Guidelines for Strenthening Regional Taxable Capacity as a Factor of Sustainable Development of the Territorial Entities
}

\author{
Basir Khabibovich Aliev \\ Liudmila Lazarevna Igonina \\ Khaibat Magomedtagirovna Musaeva \\ Magomed Magomedovich Suleymanov \\ Madina Gamidulakhovna Alimirzoeva \\ Federal state educational institution of higher professional education "Dagestan state University" \\ Russian Federation, Republic of Dagestan, 367000, Makhachkala, Gadjieva street 43 "a"
}

Doi:10.5901/mjss.2015.v6n5s2p343

\begin{abstract}
The article investigates the problem of strengthening the regional taxable capacity as a factor of sustainable development of territorial entities, as well as presents analysis of the various approaches to the study of taxable capacity. Also, the article presents the summary of the region's economic status and the structure of tax revenues in the consolidated budget depending on the region's economic activities. Authors give arguments to the main reasons for the low fiscal performance and offer proposals for the development of the taxable capacity of the region through the implementation of priority project "Whitewashing the economy". The research findings can be used by federal and regional authorities as a theoretical and methodological framework when developing proposals for the enhancement of taxable capacity of the territorial entities.
\end{abstract}

Keywords: taxable capacity, region, income base, priority project, "whitewashing the economy", fiscal performance.

\section{Introduction}

Budgeting of regional income basis depends on the institutional organization of regional economic complexes, which define features of tax policy pursued by the government. The parameters of its effectiveness include the indicators of the possible taxation mechanisms, such as taxable capacity that holds a prominent place.

The taxable capacity is the foundation to assure the financial autonomy of the Russian Federation regions. The level of its development influences the pace of socio-economic dynamics of territorial entities, the possibility of financing investment projects, and the quality of inter-budget relations. Holding a leading position in the financial assurance of the territorial entity of the Russian Federation, the taxable capacity has outcome orientation, which is associated with its use for socio-economic development of the territorial entity and ensuring an appropriate contribution to the economic development of the country.

The Republic of Dagestan, currently one of the problem (depression) regions of the Russian Federation, was chosen as the research target. This is due to the fact that for the past many years the budget of the Republic is formed mainly (over 80\%) at the expense of the federal budget. The problem on the effective implementation of tax policy and growth of taxable capacity is of particular importance at the present stage of development of the Republic of Dagestan.

\section{Methodology}

In this article, different aspects of the taxable capacity of the region are analyzed based on a systematic approach and using comparative and statistical methods. As a result of research performed, tax revenues in the consolidated budget of the Republic of Dagestan are structured depending on various economic activities. The main causes of low fiscal performance are argued and proposals for the enhancement of region's taxable capacity are developed.

Within the framework of an important priority project "Whitewashing the economy", a challenge was set to maximally legitimate the shadow economy in the region and ensure the growth of tax collection up to $10 \%$ of the gross 
regional product (GRP) by the end of 2014. The importance of the strategic position, which has the North Caucasus to Russia, and Dagestan to the North Caucasus, the integrated nature of threats from shadow economic relations, prevailing in the region, makes it necessary to analyze the causes of this phenomenon and to identify possible ways to fight with them.

Seven priority projects (Table 1) have been identified and implemented in Dagestan after the Republic was headed by R. Abdulatipov. Among these projects, the priority project "Whitewashing the economy" is of particular importance.

Table 1. Priority projects of the Government of the Republic of Dagestan

\begin{tabular}{|c|c|c|}
\hline \#. & Project title & Project goal \\
\hline 1. & "Whitewashing the economy" & $\begin{array}{l}\text { Removing the economy "out of the shadows" due to the revitalization of the local authorities and tax authorities, as } \\
\text { well as working with taxpayers. }\end{array}$ \\
\hline 2. & $\begin{array}{l}\text { "Growth points, investments and } \\
\text { efficient territorial development" }\end{array}$ & $\begin{array}{l}\text { Providing the Republic with dynamic economy "growth points" and cause economic "breakthrough." Part of the } \\
\text { project involves support of key investors. }\end{array}$ \\
\hline 3.|' & "New industrialization" & $\begin{array}{l}\text { Growing the industrial production, increasing budget revenues and employment of the population by implementing } \\
\text { new development forms of industrial potential of the Republic. }\end{array}$ \\
\hline 4. & "Efficient public administration" & $\begin{array}{l}\text { Contributing to the formation of public administration as an open, dynamic, business- and socially-oriented system. } \\
\text { It is planned to introduce the effective anti-corruption mechanisms, improving the business climate and the } \\
\text { cooperation with the active civil society. }\end{array}$ \\
\hline 5. & $\begin{array}{l}\text { "The efficient agro-industrial } \\
\text { complex" }\end{array}$ & $\begin{array}{l}\text { Establishing and developing "growth points" in the agricultural sector, launching highly profitable projects in the } \\
\text { agribusiness, creating the products logistics supply chains both within the Republic and to the RF regions, as well } \\
\text { as creating } 3 \text { major agro-industrial parks. }\end{array}$ \\
\hline 6. & "Human capital" & $\begin{array}{l}\text { Bringing training of professionals in the educational environment in line with the actual personnel demand, building } \\
\text { an effective health care system, providing integration of the Republic into international and Russian cultural space, } \\
\text { and initiating growth of social protection of the population. Studying the popular languages of Dagestan, as well as } \\
\text { Russian and English languages as one of the most important project elements. }\end{array}$ \\
\hline 7. & "Safe Dagestan" & $\begin{array}{l}\text { Ensuring actual security and creating the image of a stable region. A set of actions aimed at the prevention of a } \\
\text { crime and violation of a law, as well as reduction of the risk of terrorism will be prepared. }\end{array}$ \\
\hline
\end{tabular}

Table is compiled according to http://www.riadagestan.ru

The priority projects of the Republic of Dagestan are aiming at removing the Republic's economy from the "shadow", increasing investment attractiveness of the country, contributing to the growth of industrial production, increasing employment of the population, developing agribusiness, forming a positive recognizable image of the Republic, improving the quality of life of Dagestani, as well as education and health systems, creating qualitatively new cultural environment, ensuring the actual security and creating the image of a stable region. The basic condition for the implementation of priority projects is the availability of financial resources that in turn depends on the ongoing regional tax policy aimed at developing the region's taxable capacity.

Taxable capacity in the Republic of Dagestan is just 5\% of GRP (for comparison, in the North Caucasus tax collection amounts for $10-13 \%$ of GRP, whereas in the Russian Federation it is 26\%). Per capita income of the consolidated budget of the Republic is significantly below the national average and the lowest among the territorial entities of the Russian Federation, comprising the North Caucasian Federal District. Thus, in 2012, per capita revenues of the consolidated budget of Dagestan amounted to 27.3 thousand rubles, which is less than that for the entities of the Russian Federation on average by 56.4 thousand rubles, and for the entities of the North Caucasus Federal District - by 35.0 thousand rubles. The most important reason explaining the current situation is the high proportion of shadow economy component, which creates prerequisites for the growth of terrorism and extremism in the Region. According to unofficial information, shadow economy component in the Republic of Dagestan is over 70\% (whereas in the whole Russia it is about 40\%) (Public speaking of the Minister of Economic Affairs of the Republic of Dagestan, 2013).

\section{Results}

Just the minimum estimated taxable capacity growth in the Republic of Dagestan accounts for more than 1 billion rubles. The lowest tax burden is observed in catering consumption; at that losses include both personal income taxes and the income from the simplified tax system. For example, in Makhachkala there are 57 restaurants. Each restaurant gives about 85 thousand rubles of taxes per year, i.e. 7 thousand rubles per month that does not reflect the real situation. The number of employees, which are indicated in catering establishments, are a specific area for the tax inspection. Analysis of the database of tax authorities showed that the number of employees in 18 establishments out of the 57 is just 2-3 persons. The average salary varies from 2 to 9 thousand rubles. At that, $47 \%$ of establishments indicate the level of 
wages below the minimum statutory monthly pay (Suleimanov, 2011). A similar situation exists in other economy sectors. Table 2 shows the role of certain types of economic activities in the Republic in terms of the tax provision to the consolidated budget of the Republic of Dagestan.

Table 2. The structure of tax revenues to the consolidated budget of the Republic of Dagestan depending on economic activity for the years of 2009-2013, \%.

\begin{tabular}{|l|c|c|c|c|c|}
\hline Economic activities & 2009 & 2010 & 2011 & 2012 & 2013 \\
\hline 1. Agriculture, hunting and forestry & 1.6 & 0.9 & 1.7 & 0.7 & 7.9 \\
\hline 2. Mining & 9.7 & 6.9 & 4.3 & 4.2 & 5.9 \\
\hline 3. Manufacturing & 28.4 & 16.6 & 17.1 & 18.9 & 16.4 \\
\hline 4. Production and distribution of electricity, gas and water & 8.3 & 8.9 & 14.5 & 14.3 & 10.0 \\
\hline 5. Construction & 9.3 & 4.1 & 7.2 & 4.4 & 5.6 \\
\hline 6. Wholesale and retail trade & 4.8 & 3.6 & 0.5 & 4.3 & 5.0 \\
\hline 7. Transport and communications & 12.0 & 10.8 & 12.2 & 12.1 & 11.8 \\
\hline 8. Finance & 2.7 & 2.5 & 2.6 & 3.5 & 4.3 \\
\hline 9. Education & 6.9 & 6.2 & 8.1 & 6.9 & 6.5 \\
\hline 10. Health care and social services & 2.6 & 4.7 & 5.5 & 5.0 & 3.9 \\
\hline 11. Other types of economic activity & 13.7 & 34.8 & 26.1 & 25.7 & 22.7 \\
\hline Total & 100 & 100 & 100 & 100 & 100 \\
\hline
\end{tabular}

The data are calculated based on the statistical tax reporting of the Department of the Federal Tax Service of the Russian Federation in the Republic of Dagestan.

The high dependence of the region on the financial aid, provided from the federal budget, leads to a reduction of interest on the part of regional authorities in the economic development of their territorial entity, expansion of the tax base and improving fiscal performance at the local level. Whereas the average level of financial aid, received from the federal budget to the consolidated budgets of the Federation entities, in Russia in 2013 was 28\%, the proportion of financial aid in Dagestan was about 75\% of Republic's budget revenues; and taking into account deductions from federal regulatory taxes, it was more than $80 \%$ (Aliev, Suleymanov \& Kadieva, 2011).

The major part of the national budget revenues of the Republic of Dagestan consists of contributions from the personal income tax (9.1\% in 2013) and corporate income tax (8.2\%). Besides, excise taxes are also stable sources to replenish the budget revenues. Tax proceedings from excises during the period from 2009 to 2013 increased in absolute terms by almost twice (Suleimanov, 2011). This is, first of all, due to the federal center policy, aimed at increasing the excise taxation and the proportion of contributions to the regional budgets. Non-tax revenues are of slight fiscal importance and their contributive capacity varies at a level of about 0.3 million rubles. A marked increase in revenues is observed from corporate property tax, which increases both in absolute terms and in terms of the total income structure.

Personal income tax plays a decisive role in the replenishment of the republican and local budgets. The main problem of administrating personal income tax is the problem of tax evasion, non-declaration by individuals of their income, as well as high unemployment in the region (Suleimanov, 2011). In 2012 compared to 2011 the registered unemployment rate fell from 2.8 to $2.4 \%$ of the economically active population. The overall unemployment rate according to the methodology of the International Labor Organization (ILO) averaged $12 \%$ of the economically active population in 2012 against $12.8 \%$ in 2011. However, in the Republic of Dagestan unemployment still remains high due to outstripping growth of labor resources and the lack of a sufficient number of permanent jobs, especially in rural areas. In Dagestan, the unemployment rate is much higher than the national average. According to the ILO methodology, in 2012 it was 12\%, while an average indicator for the Russian Federation was 5.3\%. Registered unemployment amounted for $2.4 \%$, whereas an average for the Russian Federation was 1.4\% (Aliev, Suleymanov \& Kadieva, 2011).

In 2012, tax revenues into the Republic's budget, in terms of main activities per employee (13.9 thousand rubles), were almost 3 times less than that of the Stavropol Territory (40.1 thousand rubles), and 2 times less than similar indicators of the Republic of Ingushetia (26.6 thousand rubles) (Germogentova, 2000). But at the same time, in terms of the small enterprises turnover, which amounts for 136.5 billion rubles, the Republic of Dagestan holds a leading position in the North Caucasus Federal District. The same figure for the Kabardino-Balkar Republic is just 26.7 billion rubles that is 5 times less. At the same time, taxes corresponding to this activity were received in the Republic of Dagestan in amount of 707 mln rubles, while in Kabardino-Balkaria - 607 mln rubles (Kashin, 2002).

A similar situation is observed in the "construction" industry, where payroll budget in 2012 was at least $30 \%$ of the 
costs of construction and assembly works. In this industry, just the personal income taxes would have amounted to more than 2 billion rubles, taking into account all possible deductions, though actually received revenue was 3.9 times less than expected figure. In general, the construction industry can give about 8 billion rubles in taxes per year, though actually just 1.5 billion rubles was received. This is due to the various tax evasion schemes, largely widespread in Dagestan, including the payment of "shadow" wages, as well as low fiscal culture of the population. The problem of large migrant workers flows (especially in construction industry), who work mostly without an employment contract, aggravates the situation deriving profits of this category of workers from paying the personal income tax.

These problems can be resolved by the tax authorities through audits of organizations, which have signs of paying "gray" wages, as well as organizations, which do not conclude labor or civil contracts with the employees, and the organizations, in which the official wages of workers are below the industry average. Also, when implementing control measures against individuals, the effective remedy is the use of information from external sources, primarily concerning vehicle and property owners. These tasks should be among the priority guidelines of the tax authorities with regard to administration of the personal income tax (Batkibekov, Kadochnikov, Lugovoy, Sinelnikov \& Trunin, 2000).

Growth in construction volumes and the appreciation of dwelling houses have a negative impact on the effective rate of revenue from personal income taxes. The growth of housing construction volume by $1 \%$ leads to reduction of the personal income tax revenue to the budget system by $0.14 \%$ (Aliev \& Suleymanov, 2013). This is due to the possibility of obtaining a tax deduction by individuals when purchasing real estate. Due to the substantial increase in the cost of housing over the last 5 years, real estate is increasingly acquired in co-ownership by two or three persons. In addition, each property owner has the right to property-related tax deduction (which since 2011 has increased from $1 \mathrm{mln}$ rubles to $2 \mathrm{mln}$ rubles). This further reduces personal income tax revenue into the budget. Also, since January 1st, 2012, taxpayers, who receive pensions, in case of lack of income, subject to tax at the rate of $13 \%$, may carry forward the rest of the property deduction to the previous tax periods, but not more than three fiscal periods.

Renting of dwellings is another substantial reserve to increase revenues from personal income tax. Currently, the largest group of individuals, who do not file a tax return and do not pay personal income tax, consists of the premises owners, who give lodging for rent. Besides, key measures, which may increase the taxation base on personal income tax, include the following:

1) the reduction of unemployment and other negative factors affecting the amount of tax base on personal income tax;

2) legalization of all kinds of tax payers' income in their actual amount;

3) identification of organizations, which do not conclude labor or civil contracts with employees, as well as organizations, in which the official wages of workers are below the industry average (Tannenwald, 1999).

It is important to note that for the Republic of Dagestan personal income tax is very essential and meaningful, since it is one of the main sources of budget replenishment. Importance and significance of personal income tax for the budget of the Republic of Dagestan is confirmed by statistical data, namely the proportion of personal income tax in the budget revenues of the Republic. Thus, in 2010, personal income tax was 43.5\%, while in 2013 it reached its maximum of 50\%, accounting for half of all tax revenues (Suleimanov, 2011).

In 2013, the Republic of Dagestan has increased the uncompensated receipts to the budget in amount of approximately 60.1 billion rubles. Much of this money was directed to the growth of wages. As a result of these actions, the average salary in the Republic has grown from 13,400 rubles in 2012 up to 17,100 rubles in 2013. This explains the increase in the collection of personal income tax. However, the taxable capacity of the region still is not fully utilized that is manifested by the failure of the approved plans to collect taxes and fees.

The factors that have negative effect on tax flow into the budget of the Republic of Dagestan include the following:

- insufficiently effective activity of tax bodies, the lack of real cooperation of revenue administrators with public authorities and local self-government, as well as failure in conduction of joint activities to increase tax revenues in close cooperation with law enforcement agencies (the Ministry of Interior of the Republic of Dagestan) and the territorial divisions of the federal bodies of state authority (Office of the Federal Tax Service in the Republic of Dagestan, Russian State Register, and others);

- low wages and payment of "envelope wages" ("grey" salary, not officially recognized in the accounting reports);

- unemployment, including hidden unemployment;

- increase of the receivables;

- inflation and growth of consumer prices;

- change in legislation with regard to the provision of tax deductions;

- increase in the cost of residential property during the last few years; 
- exercising of various schemes for tax avoidance by organizations.

The following measures can be noted as major resources for increasing regional taxable capacity with regard to taxation of organizations' profit:

1) to improve the overall business and investment climate, as well as socio-economic situation in the region, and to increase the investment activity of organizations;

2) to improve the financial situation of low-margin businesses;

3) to identify and prevent the use of illegitimate mechanisms of reducing the tax base by taxpayers and to enhance organizations' tax discipline; note that the deliberate lowering of enterprise's profitability is the main way to reduce illegally the income tax base.

4) to increase the validity of the provided (intended) tax benefits for income tax with regard to their economic, budgetary and social efficiency;

5) to optimize the tax control process, involving quantitative and qualitative improvement of tax audits, and to tighten supervision over the taxpayers.

Taxable capacity growth reserves on organizations' property tax include the following measures:

1) general improvement of economic dynamics and greater investment activity of economic entities;

2) improvement of legislative regulation of property relations;

3) reducing the interest of organizations to minimize the property tax through the use of illegal schemes of tax avoidance (including identifying fixed assets that are not registered);

4) completion of the real property assets registry, optimization of the technical passports reproduction process for each object providing consolidation of ownership in the registration authorities (Davydova \& Fokina, 2010).

Growth reserves of land tax receipts include:

1) improvement of legal regulation of land matters;

2) optimization of granted (intended) tax incentives for land tax;

3) the completion of description and establishing the borders of municipal formations;

4) creation of a complete information base and preparation of information needed for payments of land tax based on the cadastral value of the land.

Such areas of small business as a sale of building materials, operation of concrete mixing stations, the development of stone, sand, production of cinder blocks, paving slabs, etc. almost do not pay taxes to the budgets. Most entrepreneurs involved in these activities, do not have title certificates. These activities are covered by shadow and criminal veil. Here growth reserves in tax revenue are bringing the economy out of the "shadow". It is clear that today construction organizations underpay taxes, although the volume of construction work is growing every year and accounts for a significant share in the gross regional product. Currently the contribution of such industry as construction is negligible in terms of the budget income generation.

According to the Bureau of Technical Inventory (BTI) of Makhachkala, about 95\% of the buildings and structures are assessed less than 100 thousand rubles each and accordingly pay tax not more than 100 rubles. In accordance with the current legislation, the commissioning of the objects and their acceptance into operation is carried out by the decision of local authorities and with the participation of their representatives. Therefore it is necessary to complete an inventory of housing and buildings to ensure registration of the property rights of individuals to their property. Without this measure the tax authorities are unable to lay a claim to payment of property tax.

The expansion of the tax base directly depends on the completeness of taxpayer registration database. This completeness is a major problem in the field of levying various taxes, because there are a number of difficulties when carrying out the identification of information received from the agencies. The lack of standard requirements for the database structures that are transferred to the tax authority, does not allow one to identify objects in automatic mode. A comparison of the multiple database records manually is not sufficient to ensure the reliability of information for tax computation. As a result, the number of taxpayers, who are registered with the tax authority at the location of the land plot, does not match the number of filed tax returns, which, ultimately, leads to arrears of taxes and duties.

Growth reserves of tax revenues in the regional budget are also associated with improvement in the collection rate of vehicle tax. In Dagestan, there are a lot of expensive cars owners, who do not pay transport tax. As of 2013, in Dagestan actually were registered about 540 thousand vehicles, while the tax records included only 240 thousand units that confirms the low level of tax administration in this area, as well as the lack of tax culture of the majority of potential contributors of vehicle tax (Mayburov \& Ivanov, 2014).

It is necessary to develop and adopt effective measures for the full coverage of taxation of industries in which the shadow component is quite high. In particular, it is necessary to intensify efforts focused on identification of unregistered entrepreneurs and setting them on record. Given the current situation and in order to increase the tax revenues to the 
consolidated budget of the Republic of Dagestan, it is necessary to strengthen and intensify the activity of the interdepartmental working group to increase revenues of the consolidated budget and taxable capacity, as well as to implement the measures to reduce the "shadow" economy. Along with this, it is necessary to strengthen the motivation of local governments to expand the tax base and increase tax revenues to the budget.

To improve the effectiveness of tax authorities efforts aimed at mobilization of taxes and broadening the tax base (particularly transport tax, land tax and individuals' property tax) it is advisable to intensify and coordinate the work of various ministries, departments and committees to identify additional taxation objects and assure their real taxation.

\section{Discussion}

Problems on development of regional taxable capacity have been intensively studied in the economic literature. It is regarded primarily due to the improvement of fiscal planning and intergovernmental fiscal relations. At that, the taxable capacity appears as a tool to improve the mechanism of providing financial assistance to the regions and municipalities. Also, it is the specified rate that reveals the real financial needs of the territorial entities (Istomin, 2014; Kravtsov, Magomedov \& Suleymanov, 2014; and Barro, 1986). Far fewer studies have been devoted to regional taxable capacity as economic and financial categories, as well as to the analysis not only of its quantitative but qualitative characteristics (Meshcheriakova, 2008; Mayburov, Ivanov \& Tarangul 2013; Belkin, 2000; Chernick, 1988; Tannenwald, 1999; and TerMinassian, 1997).

In particular, Chernik treats taxable capacity as the government's ability to transform the economic performance, localized within certain limits, into the costs of the public sector (Chernik, 1988). Barro treats it as the ability of the administrative-territorial entity to receive tax revenues from its own sources, regardless the level of fiscal efforts (Barro, 1986).

Economists Aliev and Suleimanov in their works consider taxable capacity both in the broad and narrow sense. Taxable capacity in the broad definition is regarded as the total amount of financial resources, which can be mobilized through the taxation system. This aspect is taken into account when assessing taxable capacity, aimed at considering the highest possible volume of taxable resources of the territorial entity. Taxable capacity in narrow definition is a financial resources, which should replenish the budget through tax payments in accordance with applicable law (Aliev, Suleymanov \& Kadieva 2011; Batkibekov, Kadochnikov Lugovoi, Sinelnikov \& Trunin, 2000; Gorski, 1999; Nasyrova 2002 ; Mayburov, Ivanov \& Tarangul, 2013). Such interpretation of the taxable capacity is used when determining the average expected tax revenues in separate territorial entities, as well as assessing tax collection and tax efforts of authorities.

Many Western scholars, as noted by Davydova and Fokina, treat taxable capacity as the per capita potential budget income, which can be received by the authorities during a certain period of time (usually a fiscal year) when applying terms of taxation, uniform throughout the country (Davydova \& Fokina, 2010).

Reflecting the aim of the relevant studies, the above definitions of taxable capacity focus on its role in the provision of regional income and do not take into account the composition and structure of tax resources, the conditions of their transformation into tax revenues and other aspects of the taxable capacity as a complex economic category.

\section{Conclusions}

In general, the following measures are recommended to improve fiscal performance in the region:

- improving the methodology to determine the objects to the tax control;

- advanced training and improving proper technical equipment of fiscal authorities employees;

- adopting a policy of educating law-abiding taxpayers.

These measures should be combined together with the measures aimed at further improving the regulations on the taxes calculation and payment procedures, as well as measures providing further industrial growth. It is important to note that along with the strengthening of the control sequence of local tax offices, an important reserve, providing the growth of tax revenues, is creation of conditions and incentives encouraging increase in production of commodities (works, services) in the economy sectors, and, respectively, broaden the tax base in the regional economy sectors. Perhaps some authors' suggestions require more in-depth theoretical study, though with all the difficulties of providing solutions to the problems discussed in this article, the proposed measures can contribute to the development of taxable capacity of the region. 


\section{Acknowledgement}

The article is published as part of the public task of the Ministry of Education and Science of the Russian Federation \#26.15.69.2014 on the subject of "Tax mechanism as a tool to control inter-regional socio-economic differentiation at the present stage". The authors express their gratitude to the Ministry of Education and Science of the Russian Federation for supporting the project.

\section{References}

Aliyev, B. \& Suleymanov, M. (2013). Strategic guidelines to improve the tax system in Russia. Finances and Credit, 42, 43-47.

Aliyev, B., Suleymanov, M. \& Kadieva, R. (2011). The taxable capacity of the region: challenges and prospects for growth. Finances and Credit, 4, 2-7.

Barro, S. (1986). State fiscal capacity measures: a theoretical critique / measuring fiscal capacity. Boston: Oelgeschager, Gunn \& Hain Publishers, Inc.

Batkibekov, S., Kadochnikov, P., Lugovoy, O., Sinelnikov, S., \& Trunin, I. (2000). Evaluation of the taxable capacity of the regions and the distribution of financial aid out of the federal budget. Improvement of intergovernmental relations in Russia. Moscow: IET.

Belkin, D. (2000). Taxing metropolis: tax effort and tax capacity in large US cities. N.-Y.: Independent Budget Office.

Chernick, H., (1988). Fiscal capacity in New York: the city versus the region. National Tax Journal, $51,3$.

Davydova, L. \& Fokina, O. (2010). Comparative characteristics and the choice of method for estimating the taxable capacity of the region. Finances and Credit, 5(389), 15.

Gorsky, I. (1999). Taxable capacity in the mechanism of intergovernmental relations. Finances, 6.

Germogentova, M. (2000). Some analytical issues of financial categories. Bulletin of the Finance Academy, 2.

Istomina, N. (2014). The redistribution of the budget in the performance-based budgeting. Financial Analytics: Problems and Solutions, $27,42$.

Kashina, N. (2002). Taxable capacity in the budget forecasting. Finance, 2.

Kravtsova, N., Magomedova, R. \& Suleymanov, M. (2014). Fiscal decentralization as the basis for the formation of an effective fiscal policy in the region. Regional Economics: Theory and Practice, 10, 7-15.

Mayburov, I., Ivanov, Yu. \& Tarangul, L. (2013). The economy of tax reforms. Kiev.

Meshcheriakova, L. (2008). Evaluation of the regional potential to increase tax revenues. Regional Economics: Theory and Practice, 7 (64).

Mayburov, I. \& Ivanov, J. (2014). Tax and taxation. The palette of contemporary issues. Moscow, Magister.

Nasyrova, V. (2002). Tax potential and its realization in the system of regional tax revenues. PhD thesis, Kazan.

Suleymanov, M. (2011). Growth reserves of taxable capacity of the Republic of Dagestan. Regional Economics: Theory and Practice, $39,9-13$.

Tannenwald, R. (1999). The representative tax system - tax capacity and tax effort in the Ocean State. Retrieved from http://www. ripec.com/rts.

Ter-Minassian, T. (1997). Fiscal federalism in theory and practice. Washington, D.C., IMF.

Yusufov, R. (2013). Public speaking of the Minister of Economic Affairs of the Republic of Dagestan at a meeting of the Council of Heads of municipal and urban districts under the President of the Republic of Dagestan. Buynaksk. Retrieved June 5, 2013 from http://www.dagetstantimes.com 